\title{
Peningkatan Usaha Beternak Ayam Petelur pada Kelompok Peternak Unggas Dusun Tukak Bendu Santong Mulia Kayangan Kabupaten Lombok Utara
}

\author{
D. K. Purnamasari,* Syamsuhaidi, K.G. Wiryawan, Erwan, Sumiati, \\ Pardi, Tjok S. Binetra \\ Fakultas Peternakan Universitas Mataram, Jl. Majapahit No.62 Mataram 83125
}

\author{
Article history \\ Received: 13-04-2021 \\ Revised: 25-06-2021 \\ Accepted: 11-07-2021 \\ *Corresponding Author: \\ D.K. Purnamasari, \\ Fakultas Peternakan \\ Universitas Mataram, \\ Mataram, Indonesia; \\ Email: \\ emmadkp03@gmail.com
}

\begin{abstract}
The productivity of laying hens in North Lombok Regency has not yet reached its maximum. Egg production has not been able to supply the needs of the people, hotels and restaurans in North Lombok Regency. Assistance activities from various parties are needed in order to improve the business of laying hens through the share of science, technology, and training in livestock. The community service activity was initiated by a speech from the head of the breeders group who revealed the various problems by breeders in improving their poultry farming business. The next activity was the share knowledge of community service which include successful management of laying hens, techniques for preparing various feed formulas by utilizing and techmiques for improving the quality of alternative feeds. The community service activity was attended by 35 breeders and the discussion was active. The breeders who attended were farmers who are members of the 'Gemas' Layer Farmer Group Associantion, which has 23 members with a business capacity of 20.000 layer hens. The farmer group is eager to increase egg production in order the needs of hotels, restaurants, people in North Lombok Regency. Through the use of alternative feeds by arranging variouse feed formulas according to the needs of liverstock is a solution that can be applied to increase the quantity and quality of eggs.

Keywords: complete feed; alternative feed; quantity; quality; egg
\end{abstract}

Abtrak: Produktifitas peternakan ayam petelur di Kabupaten Lombok Utara belum mencapai maksimal. Produksi telur belum mampu mensuplai kebutuhan masyarakat, hotel-hotel dan restauran-restauran di Kabupaten Lombok Utara. Kegiatan pendampingan dari berbagai pihak sangat diperlukan dalam rangka meningkatkan usaha peternakan ayam petelur melalui penyampaian ilmu pengetahuan, teknologi, dan pelatihan dalam beternak. Kegiatan pengabdian diawali penyampaian sambutan dari ketua kelompok peternak yang mengungkapkan berbagai permasalahan yang dihadapi oleh peternak dalam meningkatkan usaha peternakan unggas. Kegiatan selanjutnya penyampaian materi pengabdian yang meliputi managemen beternak ayam petelur yang berhasil, teknik penyusunan berbagai formula pakan dengan memanfaatkan pakan alternatif, dan teknik peningkatan kualitas pakan alternatif. Kegiatan pengabdian diikuti oleh sekitar 35 orang peternak dan diskusi berjalan dengan aktif. Peternak yang hadir adalah peternak yang tergabung dalam Asosiasi Kelompok Peternak Ayam Petelur 'GEMAS' yang beranggota 23 peternak dengan kapasitas usaha 20.000 ayam petelur. Kelompok peternak semangat ingin meningkatkan produksi telur agar dapat memenuhi kebutuhan hotel, restauran, rumah tangga di Kabupaten Lombok Utara. Melalui pemanfaatan pakan alternatif dengan menyusun berbagai formula pakan yang sesuai dengan kebutuhan ternak merupakan solusi yang dapat diterapkan untuk meningkatkan kuantitas dan kualitas telur.

Kata Kunci: pakan kompit; pakan alternatif; kuantitas; kualitas; telur 


\section{PENDAHULUAN}

Kabupaten Lombok Utara merupakan salah satu kabupaten termuda di Propinsi Nusa Tenggara Barat, yang dibentuk berdasarkan Undang-Undang Nomor 26 Tahun 2008 yang merupakan pemekaran dari kabupaten Lombok Barat. Memiliki luas $809,50 \mathrm{Km}^{2}$ dan secara geografis berada di Kaki Utara Gunung Rinjani. Daerah ini memiliki sejumlah objek Wisata yang cukup terkenal di Mancanegara, seperti Gili Terawangan, Gili air, Gili Meno, Air Terjun Sendang Gile Bayan, serta keindahan Danau Segare Anak yang ada di puncak Rinjani dan masih banyak obyek wisata lainnya. Ditinjau dari keadaan geografisnya Kabupaten Lombok Utara terbagi menjadi: Daerah Pegunungan, yaitu gugusan pegunungan yang membentang dari Kecamatan Bayan sampai Kecamatan Pemenang. Gugusan pegunungan ini merupakan sumber air sungai yang mengalir ke wilayah-wilayah daratan dan bermuara di sepanjang pesisir pantai (Pemda KLU, 2016).

Berdasarkan keunggulan sebagai daerah pariwisata, kabupaten Lombok Utara mulai membangun daerah dalam berbagai aspek baik pendidikan, pertanian, perkebunan, perdagangan, dan termasuk bidang peternakan yang diharapkan mampu menunjang bidang pariwisata. Pertanian merupakan penopang perekonian masyarakat Kabupaten Lombok Utara. Indikasi tersebut diperkuat oleh sebagian besar penduduk Kabupaten Lombok Utara bekerja di sektor pertanian. Lahan yang luas dan tanah yang subur merupakan modal yang sangat penting bagi peningkatan pertanian di Kabupaten Lombok Utara. Sektor pertanian yang menjadi primadona adalah pertanian tanaman pangan dan perkebunan. Sektor lain seperti peternakan, perikanan dan kehutanan juga cukup memberikan andil yang signifikan terhadap perkembangan perekonomian di Kabupaten Lombok Utara.

Pada Bulan April 2016 Bupati Kabupaten Lombok Utara (KLU) telah secara resmi mengukuhkan Lembaga Asosiasi Peternakan Unggas Gerbang Telur Emas (Gemas) Dusun Tukak Bendu Desa Persiapan Santong Mulia Kecamatan Kayangan Kabupaten Lombok Utara. Program pengembangan bidang peternakan bertujuan untuk menanggulangi masalah gizi, meningkatkan ekonomi masyarakat dan kemandirian warga, serta diharapkan mampu mensuplai kebutuhan daging dan telur masyarakat dan untuk menunjang kebutuhan sebagai daerah pariwisata, sehingga ketahanan pangan daerah dapat tercapai.

Untuk menunjang program pemerintah bidang peternakan dibutuhkan keterlibatan berbagai pihak terutama akademisi, yang diharapkan dapat memberikan sumbangan pemikiran dan ide-ide yang bersumber dari berbagai ilmu, pengalaman dan hasil hasil penelitian yang dapat diterapkan di masyarakat. Berdasarkan pengamatan di lapangan, bahan baku pakan ternak tersedia di Kabupaten Lombok Utara, seperti jagung, dedak, bungkil kedelei dan limbah pertanian lainnya, namun perlu dipertimbangkan produksinya agar mampu tersedia sepanjang masa mengingat kabupaten Lombok Utara termasuk daerah yang kekurangan air ketika musim kemarau berkepanjangan. Penyediaan bahan baku pakan ternak dapat berpengaruh terhadap perkembangan pakan ternak dan perkembangan usaha peternakan, khususnya ayam petelur.

Ayam petelur merupakan ayam hasil rekayasa genetik yang memiliki kemampuan menghasilkan telur dalam jumlah banyak dengan masa bertelur yang lama, dengan tingkat efisiensi pakan yang baik. Namun demikian, ayam petelur modern ternyata memiliki beberapa beberapa kelemahan, yaitu relatif sulit mencapai berat badan standar terutama ketika fase starter serta memasuki awal produksi hingga puncak. Ketertinggalan berat badan tersebut sulit dikompensasi saat fase pemeliharaan berikutnya. Selain itu ayam petelur modern lebih sensitif terhadap perubahan lingkungan dan pakan (Medion, 2014). Penerapan tata laksana pemeliharaan yang baik, seekor ayam petelur mampu menghasilkan 420 butir telur selama satu kali siklus produksi (umur 18-90 minggu). Ayam petelur mulai berproduksi ketika mencapai umur 18 minggu. Pada umur tersebut, tingkat produksi telur baru mencapai sekitar 3,8\% dan selanjutnya akan terus mengalami peningkatan secara cepat 
hingga mencapai puncak produksi yaitu sekitar 94-96\% dalam kurun waktu \pm 2 bulan (di umur 26 minggu). Produksi telur diketahui telah mencapai puncaknya apabila selama 5 minggu berturut-turut persentase produksi telur sudah tidak mengalami peningkatan lagi. Sesuai dengan pola siklus bertelur, maka setelah mencapai puncak produksi, sedikit demi sedikit jumlah produksi mulai mengalami penurunan secara konstan dalam jangka waktu cukup lama (selama 52-62 minggu sejak pertama kali bertelur). Laju penurunan produksi telur secara normal berkisar antara 0,4-0,5\% per minggu (ISA Brown Management Guide, 2019 dalam Medion, 2014).

Menurut Direktorat Jenderal Peternakan, bahwa populasi ayam ras di Indonesia mengalami peningkatan sebesar 0,61\% dalam kurun waktu 2000-2012,namun belum diiringi dengan peningkatan produktivitas ayam petelur. Oleh karena itu perlu dilakukan usaha untuk meningkatkan produktivitas ayam petelur, salah satunya melalui perbaikan sistem pemeliharaan (Setiawati, dkk., 2016). Produktivitas ayam petelur masih relatif rendah karena sistem pemeliharaan dan manajemen pakan yang kurang baik. Sistem pemeliharaan yang sangat berpengaruh adalah suhu lingkungan selama pemeliharaan. Suhu lingkungan akan mempengaruhi konsumsi, produksi dan kualitas telur, baik kualitas internal maupun eksternal. Gunawan dan Sihombing (2004) menyatakan, suhu lingkungan yang tinggi menurunkan performa produksi telur baik pada ayam petelur maupun pada ayam kampung. Suhu di atas kisaran $21^{\circ} \mathrm{C}-24^{\circ} \mathrm{C}$ akan menurunkan konsumsi pakan, dikarenakan terjadi peningkatan konsumsi air minum yang dipergunakan untuk menstabilkan suhu tubuh ayam. Hasil penelitian Setiawati, dkk. (2016), bahwa ayam petelur yang dipelihara pada kandang cage dengan suhu netral $\left(18^{\circ} \mathrm{C}\right)$ menghasilkan performa produksi yang lebih baik dan kualitas interior telur yang tinggi, sedangkan parameter bentuk telur, keutuhan dan kebersihan kerabang, dan abnormalitas, tidak dipengaruhi oleh suhu tetapi lebih dipengaruhi oleh genetik dan sistem perkandangan. Selain faktor suhu lingkungan, genetik, dan perkandangan, produktifitas ayam dominan dipengaruhi oleh manajemen pemberian pakan. Kualitas ayam petelur pada fase produksi dipengaruhi oleh manajemen pemeliharaan pada fase pullet atau fase-fase sebelumnya. Kualitas yang bagus adalah pada umur 1822 minggu ayam memasuki fase bertelur dengan tingkat produksi telur, berat telur dan lama puncak produksinya sesuai standar. Baerdasarkan standar produksi CP 909, yaitu produksi komulatif selama 62 minggu masa produksi (umur 18-80 minggu) adalah sebesar 22,1 kg per ekor atau setara dengan 351 butir telur per ekor (Dwiyanto, 2020). Lebih lanjut dinyatakan pada fase produksi terdapat titik kritis, dimana ayam akan mengalami perubahan hormonal untuk persiapan mencapai puncak produksi telur, sehingga pada fase produksi dibutuhkan perhatian lebih agar produksi tidak turun secara drastis tapi produksi tetap stabil. Pemeliharaan ayam petelur secara umum dibagi atas 3 periode, yaitu periode starter, grower, dan layer. Di masing-masing periode ini, kebutuhan nutrisi ayam petelur berbeda-beda, seperti tercantum dalam Tabel 1 .

Tabel 1. Kebutuhan Nutrisi Ayam Petelur Berbagai fase Pemeliharaan.

\begin{tabular}{|c|c|c|c|c|c|c|}
\hline Nutrisi & $\begin{array}{c}\text { Starter } \\
(0-4 \mathrm{mgg})\end{array}$ & $\begin{array}{c}\text { Grower I } \\
(>4-10 \\
\text { mgg })\end{array}$ & $\begin{array}{c}\text { Grower } 2 \\
(>10-16 \\
\text { mgg })\end{array}$ & $\begin{array}{c}\text { Pre Layer } \\
\text { (.16 mgg-produksi } \\
\text { telur } 2 \%)\end{array}$ & $\begin{array}{c}\text { Layer } \\
\text { (produksi telur 2\%- } \\
\text { umur } 28 \mathrm{mgg} \text { ) }\end{array}$ & $\begin{array}{l}\text { Layer } \\
\text { (28 mgg - } \\
\text { afkir) }\end{array}$ \\
\hline Kadar Air \%** & $<14$ & $<14$ & $<14$ & $<14$ & $<14$ & $<14$ \\
\hline EM $(\mathrm{kkal} / \mathrm{kg})^{*}$ & 2950 & 2850 & 2750 & 2750 & 2750 & 2750 \\
\hline Protein $(\%)^{*}$ & 20,5 & 20 & 16,8 & 17,5 & 18 & 17 \\
\hline Serat $(\%)^{* *}$ & $<6,5$ & $<7$ & $<7$ & $<7$ & $<7$ & $<7$ \\
\hline Lemak $(\%) * *$ & $2,5-7$ & $2,5-7$ & $2,5-7$ & $2,5-7$ & $3,3-3,7$ & $2,5-7$ \\
\hline $\mathrm{Abu}(\%)^{* *}$ & $5-8$ & $5-8$ & $5-8$ & $10-14$ & $10-14$ & $10-14$ \\
\hline Kalsium $(\%)^{*}$ & $1,05-1,1$ & $1-1.2$ & $1-1,2$ & $2,0-2,1$ & $3,25-4$ & $3,6-4$ \\
\hline Phospor $(\%)^{*}$ & 0,48 & 0,44 & 0,40 & 0,47 & 0,40 & $0,33-0,37$ \\
\hline
\end{tabular}

Sumber: * ISA Nutrition Management Guide (2010) dalam Medion (2014)

** Standar Nasional Indonesia SNI (1995) dalam Medion (2014) 
Tingkat efisiensi pemberian pakan dapat dipengaruhi oleh bentuk dari pakan. Penelitian Marzuki dan Rozi (2018), bahwa penggunaan pakan dalam bentuk crumble mempengarui HDP ayam petelur, dimana ayam yang mendapat pakan bentuk crumble menghasilkan produksi telur 6051 butir atau $315,6 \mathrm{~kg}$, sedang ayam yang mendapat pakan dalam bentuk mash menghasilkan produksi telur 4838 butir atau 255,5 kg selama pemeliharaan (umur 20- 28 minggu). Hal ini menandakan bahwa pakan bentuk crumble mampu meningkatkan efisiensi pakan dengan mengurangi tingkat pakan yang tercecer. Berbagai inovasi dilakukan dalam membuat formula pakan ayam pelur yang berkualitas untuk meningkatkan produktifitas. Kualitas pakan dapat dilihat dari kondisi fisik dan kandungan nutrisinya. Ayam petelur menyukai pakan dengan warna yang menarik, masih segar, tidak berbau apek, tidak terkontaminasi jamur, kutu, maupun benda lain yang tidak termasuk dalam kategori bahan pakan. Penurunan kondisi fisik pakan akan menurunkan palatabilitas pakan dan pada akhirnya akan menurunkan konsumsi pakan. Di samping itu kandungan nutrisi pakan juga akan mempengaruhi konsumsi ayam. Formula pakan dengan kandungan energi yang tinggi, berserat tinggi dan bersifat bulky akan cepat memenuhi lambung ayam sehingga ayam akan berhenti makan, sedangkan kebutuhan nutrisi lainnya belum terpenuhi (Medion, 2020). Begitu juga sebaliknya formula pakan yang rendah akan energi dan tinggi protein menyebabkan ayam akan mengkonsumsi pakan terus menerus untuk memenuhi kebutuhan energi, sehingga konsumsi pakan menjadi berlebih dan tidak efisien. Untuk itu keimbangan protein dan energi pakan pada ayam harus diperhatikan dengan baik

Hasil penelitian Sutrisna dan Sholeh (2018), yang meneliti tentang performa ayam persilangan (F2) yang diberi ransum dengan kadar protein dan dosis herbal berbeda, menghasilkan bahwa kadar protein berpengaruh terhadap konsumsi protein kasar, sedangkan pemberian herbal berpengaruh terhadap produksi hen day, sedangkan interaksi kadar protein dan pemberian herbal tidak menunjukkkan pengaruh nyata. Lebih lanjut dihasilkan, bahwa pakan berprotein kasar lebih tinggi yaitu 18\% menunjukkan konsumsi protein kasar lebih banyak. Suprijatna et al. (2006) menyatakan bahwa perlakuan perbedaan protein (18\%) dalam pakan menghasilkan konsumsi pakan yang berbeda nyata lebih banyak daripada pakan dengan protein $15 \%$ dan $12 \%$ protein.

\section{METODE}

Kegiatan pengabdian masyarakat ini dilaksanakan dalam bentuk:

1. Diskusi bersama-sama mencari penyebab permasalahan yang timbul dan memecahkan permasalahan tersebut dengan solusi yang tepat secara bersama-sama.

2. Memberikan materi penyuluhan kepada peternak tentang yang meliputi:

a) Penyampaian materi manajemen pemeliharaan ayam petelur, mulai dari penentuan bibit ayam, perkandangan, pemberian formula pakan, pencegahan penyakit, dan analisis usaha.

b) Pengenalan berbagai macam bahan pakan alternatif dan bahan pakan lokal, komposisi nutrisi dan manfaat serta penggunaannya bagi unggas.

c) Penyusunan formula pakan ayam dengan memanfaatkan bahan pakan alternatif dan bahan pakan lokal dengan memperhatikan kebutuhan dari ternak, komposisi dan harga dari bahan pakan yang dipergunakan.

d) Penyampaian cerita sukses dari seorang peternak yang sukses beternak ayam dengan kandang close house dengan jumlah ayam \pm 250.000 ekor.

3. Selesai penyampaian materi, kegiatan dilanjutkan dengan diskusi. Berdasarkan sesi diskusi akan diketahui tingkat pemahaman peserta penyuluhan terhadap materi yang diberikan dan untuk mengetahui perubahan semangat dan motivasi dalam memelihara ayam petelur dalam 
meningkatkan produktifitas untuk memenuhi kebutuhan masyarakat dan konsumen di Kabupaten Lombok Utara.

4. Evaluasi kegiatan dilakukan berdasarkan jumlah kehadiran peserta penyuluhan, keaktifan di dalam proses diskusi, perubahan sikap dan semangat, serta yang terpenting adanya komitmen dari kelompok peternak dan instansi terkait di Kabupaten Lombok Utara dalam mendampingi dan mendukung usaha peternak dalam meningkatkan produktifitas ternak.

\section{HASIL DAN PEMBAHASAN}

Kegiatan pengabdian diawali dengan melakukan pertemuan dengan Ketua Asosiasi Peternakan Unggas Gerbang Telur Emas (Gemas), Pengurus Desa Tukak Bendu, dan Pejabat Instansi Terkait di KLU., seperti tersaji pada Gambar 1. Berdasarkan hasil diskusi maka didapatkan gambaran analisis situasi berupa faktor pendukung dan faktor penghambat, yaitu:

Faktor Pendukung

a) Masyarakat setempat mempunyai semangat yang sangat tinggi untuk berusaha di bidang peternakan khususnya ayam ras petelur, untuk memenuhi kebutuhan telur baik bagi untuk konsumsi masyarakat sendiri maupun untuk memenuhi kebutuhan restauran-restauran dan hotelhotel di Kabupaten Lombok Utara.

b) Selain itu Daerah Lombok Utara merupakan daerah luas dan masih banyak tersisa lahan kosong, sehingga bila dijadikan tempat atau kawasan peternakan ayam sangat memungkinkan dan tidak akan mengganggu lingkungan pemukiman penduduk.

c) Limbah pertanian dan perkebunan tersedia sebagai bahan pakan alternatif.

Faktor Penghambat

a) Jarak yang jauh lokasi peternakan dengan pabrik/penjual pakan dan bibit, sehingga biaya transportasi menjadi tinggi. Peternak harus menempuh jarak 60-70 km ke Kota Mataram untuk membeli pakan dan bibit. Hal inilah yang menyebabkan perusahaan mitra tidak memiliki peternak mitra atau tidak mengembangkan usaha sampai ke Kabupaten Lombok Utara.

b) Kualitas telur yang dihasilkan masih kurang bisa bersaing dengan telur yang masuk dari luar kabupaten baik dari segi kualitas maupun harga.

Kegiatan Selanjutnya adalah penyampaian materi penyuluhan yang diawali dengan penyampaian kata sambutan dari Ketua Asosiasi Gemas, lalu dilanjutkan Pejabat Daerah Terkait Kabupaten Lombok Utara, dan selanjutnya sambutan sekaligus penyampaian materi oleh Ketua dan Anggota Tim Pengabdian. Materi yang disampaikan adalah:

1. Manajemen beternak ayam petelur, faktor-faktor yang memepengaruhi produksi telur, managemen pemeliharaan, peluang dan dukungan sumber daya alam dalam penyediaan pakan unggas khususnya ayam ras petelur serta bagaimana usaha peternakan dilakukan secara berkelompok.

2. Pemanfaatan bahan-bahan pakan lokal alternatif, jenis-jenis bahan pakan lokal, teknik pengolahan untuk meningkatkan protein dan menurunkan kadar serat kasar bahan, dan teknik penyusunan formula pakan.

3. Penyempaian cerita sukses dari seorang alumni fakultas peternakan yang memiliki usaha ayam kandang close house dengan kapasitas ayam mencapai 250.000 ayam. Diawali dengan usaha beternak dalam skala kecil lalu lama kelamaan meningkat jumlah dan teknologi yang digunakan, namun majunya usaha tidak terlepas dari jatuh bangunnya usaha yang diakibatkan oleh serangan penyakit, melonjaknya harga pakan, dan permainan pasar. Jiwa pantang menyerah harus tertanam dalam jiwa peternak dan berusaha mencari solusi bersama-sama dalam memecahkan 
permasalahan yang dihadapi, serta keinginan belajar harus terus ditingkatkan agar peternak menjadi ahli di dalam menjalankan usahanya.

Selanjutnya kegiatan dilanjutkan dengan sesi diskusi, sebagian besar peternak mengajukan pertanyaan seputaran permasalahan yang dihadapi dan solusi yang diberikan sebagai berikut:

a) Permasalahan biaya pakan yang besar dengan adanya biaya transpor yang tinggi. Solusinya peternak harus menjalankan usaha secara berkelompok, dengan manajemen kelompok diatur melalui AD/ART kelompok. Dengan adanya kelompok ini maka pengadaan bibit, pakan dan obat-obatan dapat diadakan secara berkelompok sehingga dapat menekan biaya pakan. Manfaat dengan adanya kelompok adalah mudah mendapatkan bantuan dari pemerintah daerah, serta informasi dan teknologi baru lebih cepat diterima. Bila kelompok sudah berjalan dengan baik dan maju, maka tidak menutup kemungkinan akan dibangun pabrik pakan mini dan tidak menutup kemungkinan perusahaan mitra akan membuka usahanya di Kabupaten Lombok Utara.

b) Permasalahan permodalan, pemerintah daerah yaitu instansi terkait berkomitmen untuk membantu dengan membuat MOU kerjasama dengan badan-badan permodalan untuk memberikan bantuan modak usaha bagi peternak dengan bunga yang ringan. Untuk itu peningkatan usaha peternakan harus lebih ditingkatkan dengan memaksimalkan kerja kelompok sehingga akan memudahkan kelompok dalam mendapatkan pinjaman modal dan bantuan dari pemerintah baik bantuan berupa materi atau kegiatan kegiatan pelatihan, bantuan bibit, pakan, dan obat-obatan. Harapan untuk menjadikan Kabupaten Lombok Utara sebagai 'Kawasan Sejuta Telur' dapat terbentuk di masa mendatang.

c) Permasalahan tentang berbagai penyakit yang menyerang ternak, dijelaskan oleh tim penyakitpenyakit umum yang menyerang ayam dan cara mengatasi dan mengobati ternak.

Diskusi berjalan dengan ramai dan lancar selama 3 jam, peternak puas mendapatkan banyak pengetahuan dan motivasi, serta yang terpenting hasil kegiatan ini melahirkan komitmen yang kuat dari insatansi terkait untuk meberikan pendampingan kepada kelompok peternak ayam petelur dan komitmen dari peternak untuk semangat mengembangkan usaha ayam petelur secara berkelompok dengan mematuhi aturan kelompok yang dibuat. Situasi dan kondisi kegiatan tersaji pada Gambar 2.

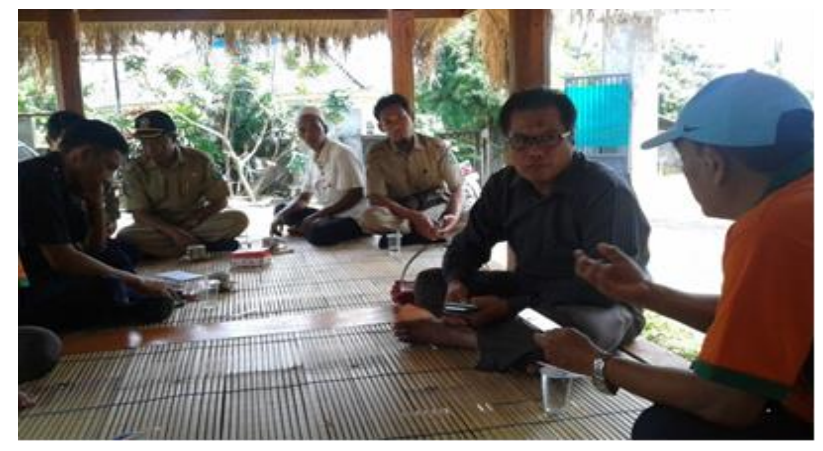

Gambar 1. Diskusi Tim Pengabdian dengan Ketua Lembaga Gemas dan Instansi Terkait Daerah KLU

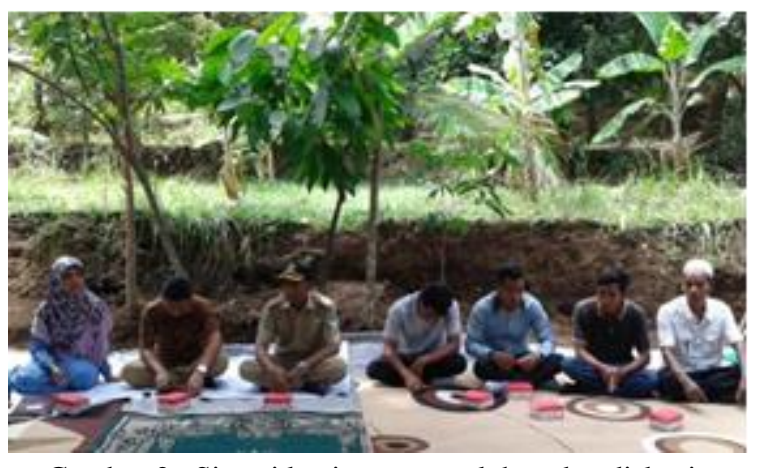

Gambar 2. Situasi kegiatan penyuluhan dan diskusi

Diharapkan kelompok peternak ayam petelur 'GEMAS' menjadi kelompok peternak yang sukses yang mampu mensuplai kebutuhan telur bagi masyarakat, restauran-restauran dan hotel-hotel di Kabupaten Lombok Utara dan menjadi contoh bagi peternak dan masyarakat lainnya untuk bersamasama menjadikan Kabupaten Lombok Utara menjadi 'Kawasan Sejuta Telur”. 


\section{KESIMPULAN DAN SARAN}

\section{Kesimpulan}

Peternak memiliki semangat dan respon yang tinggi terhadap kegiatan pengabdian ini dan mereka sangat mengharapkan pendampingan serta pembimbingan dilakukan secara kontinyu. Terjadi perubahan kesadaran dan selanjutnya terbentuknya kesepakatan diantara anggota kelompok peternak akan pentingkan memaksimalkan organisasi kelompok dalam rangka meningkatkan efisiensi usaha. Kegiatan pengabdian menghasilkan komitmen dari instansi terkait untuk membantu dalam pendampingan usaha beternak pada kelompok peternak ayam petelur di Kabupaten Lombok Utara.

\section{Saran}

Kelompok peternak unggas yang ada perlu mendapat perhatian yang serius baik dari akademisi maupun dari instansi terkait dalam pembinaan terhadap kelompok peternak unggas secara berkesinambungan.

\section{DAFTAR PUSTAKA}

Pemda KLU, 2016. Profil Kabupaten Lombok Utara. http://www.lombokutarakab.go.id. (20 april 2016)

Dwiyanto, S., 2020. Manajemen Pakan Ayam Petelur Fase Produksi. https://poultryindonesia.com/. (5 Maret 2021).

Gunawan, Sihombing DTH. 2004. Pengaruh suhu lingkungan tinggi terhadap kondisi fisiologis dan produktivitas ayam buras. Wartazoa. 14(1): 31-38

Marzuki, 4A., B. Rozi, 2018. Pemberian Pakan Bentuk Cramble dan Mash Terhadap Produksi Ayam Petelor. Jurnal Ilmiah INOVASI, Vol. 18 No. 1 Edisi Januari April 2018.

Medion, 2020. Optimalkan Konsumsi Ransum Ayam Petelur. https://www.medion.co.id/id/. (1 Maret 2021).

Medion, 2014. Mempelajari Pola Pembrian Ransum Ayam Petelur. https://www.medion.co.id/id/. (1 Maret 2021).

Setiawati1, T., R. Afnan2, N. Ulupi2, 2016. Performa Produksi dan Kualitas Telur Ayam Petelur pada Sistem Litter dan Cage dengan Suhu Kandang Berbeda. Jurnal Ilmu Produksi dan Teknologi Hasil Peternakan Vol. 04 No. 1 Januari 2016

Suprijatna, E., L.D., Mahfudz, dan W. Sarengat. 2006. Performans Produksi Telur Ayam Arab Akibat Pemberian Ransum Berbeda Taraf Protein Saat Pertumbuhan. Proseeding Seminar Nasional Teknologi Peternakan dan Veteriner. Hal. 656-662.

Sutrisna, R dan M. S. Sholeh, 2018. Performa Ayam Hasil Persilangan (F2) Yang Diberi Ransum Kadar Protein Dan Dosis Herbal Berbeda. Jurnal Ilmiah Peternakan Terpadu Vol. 6(2): 117121, Juli 2018. 